\title{
The Challenges of Educational Philosophies in the Cultural Space of Latvia
}

\author{
Pavels Jurs, (PhD) \\ Researcher of Liepaja University Institute of Educational Sciences, Latvia \\ Inta Klasone, (PhD) \\ Professor of Liepaja University, Latvia
}

doi: 10.19044/esj.2017.v13n16p32 URL:http://dx.doi.org/10.19044/esj.2017.v13n16p32

\begin{abstract}
The authors of the publication have updated the importance of the philosophy of education in the cultural space of Latvia. This study has gained significance within the context of personal development and teacher professionalism. However, existing tendencies and regulatory frameworks must be taken into account. In the context of educational theory a topical issue is: How to implement the teaching purposefully according with the external and internal factors and the influence of individual's psychological processes and at the same time maintaining the continuity and succession and providing support for the harmonious and comprehensive development of personality? The author's propose that by implementing a regulatory framework and the analysis of theoretical literature, to evaluate and update, the importance of teacher's professional dispositions their educational philosophy, and being mindful of the personality formation will lend to a balanced educational process. The 21st century is characterized by dynamism and rapid change, which consists of both benefits and challenges, e.g. increasing international competition, migration and multiculturalism, technological progress etc. That is reinforced by the transformation of sociocultural, humanitarian crisis and the revision of fundamental cultural values (Alijevs, 2005. Thus teacher`s and student`s interaction gains importance and being aware of that through recognizing the social and environmental challenges and the features of personal development, diverse educational process, different types of support is provided to students and their competitiveness and competences are promoted.
\end{abstract}

Keywords: Culture, educational process, European Union, philosophy of education, student, teacher 


\section{Introduction}

Qualitative education process provide a set of basic knowledge, enriches and develops individual talents, helps people acquire life skills and to understand themselves, to determine the attitude towards themselves and the world around them; thus finding a place in life. According to the philosopher H. G. Gadamer's view, education is directly related to the culture and primarily represents the formation of natural human ability of skills (Gadamer, 1999. While the educational philosophy focuses on education problems, analyses teaching process and the basic principles, goals, values, ideals of learning (Siegel, 2009). And thus the interaction of education (school) and individual (society) becomes an important component (Огурцов, Платонов, 2004).

The 21st century can be characterized by dynamism and rapid change, which consists of both benefits and challenges, for instance, increasing international competition, migration and multiculturalism, technological progress etc. That is reinforced by the transformation of sociocultural, humanitarian crisis and the revision of fundamental cultural values (Alijevs, 2005). Today's social reality is very variable, it is experiencing obvious transformation, which is mainly associated with man-made values crisis, geopolitical crisis, the financial crisis, cross-cultural clashes (Huntington, 1996), the humanitarian crisis in both Western and Eastern societies. The problems of co-existence of different cultures, the issues of interpretation of religious and political ideology and manipulation attempts have led to the polarizing society and a review of both people's attitudes and behaviour is required. For all these reasons educators, researchers, politicians and society are trying to find answers to the question: How can we prepare students for life in a changing era of globalization?

Teachers involved in the implementation of education, are responsible for the pedagogical process, awareness of duties and rights as well as personal professional development. While learning process for students is an important driving force leading to the development of life. It can be assumed that learning is the key to the subjective quality of life and at the same time the individual's interest in life (Helds, 2004).

Integrity of the pedagogical process is one of the central problems of the theory and practice (Špona, 2001). Nowadays, we are exposed to rapidly changing conditions; a person since his/her childhood is subjected to various public authorities, regulations and institutions. This marks the need to raise questions about the teacher's ability to exercise the proper functioning of the contemporary educational progress in philosophy and teaching culture in accordance with the constituent aspects of personality.

In the context of educational communities question how to purposefully implement the (1) teaching according to the external and 
internal factors of an individual's psychological processes, (2) maintaining the continuity and succession, (3) providing support for the harmonious, (4) contributing to the comprehensive development? The object of the research is the implementation of educational process nowadays. The subject of the research is: the tendencies of education guidance. The goal of the article is: on the basis of the regulatory framework and the analysis of theoretical literature, to evaluate and update the importance of teacher's professional work, being aware of the topicality of educational philosophy, in personality formation process and creating a balanced development of educational process. Research methods: theoretical research methods - the analysis of theoretical literature in the fields of pedagogy, psychology, philosophy and sources (documents).

\section{The dimension of education and personality}

The current issues of the education implementing in the context of personality development

In the result of programming document research it can be concluded that the implementation of the education of Latvia is based on the four basic types of learning of the UNESCO report, which includes:

- learning to know, in the sense of mastering tools for understanding, operating in the fields of interest;

- learning to do in order to successfully be able to operate in the environment of interest, acquiring both skills and new competences of individual and team collaboration;

- learning to live together, to attend and participate together with other students, appreciating and respecting the values of others;

- learning to be in the development of their personality, showing selfsufficiency and personal responsibility (Delors, 2001).

Council Resolution (2009/C 311/01) on a renewed framework for European cooperation in the youth field (2010-2018) have put forward one of the aim - "young people's creativity and capacity for innovation should be supported through better quality access to and participation in culture and cultural expressions from an early age, thereby promoting personal development, enhanced learning capabilities, intercultural skills, understanding and respect for cultural diversity and the development of new and flexible skills for future job opportunities”. In this context, the European Council has set a number of priorities:

- "support the development of creativity among young people by following up the Council conclusions on promoting a creative generation: developing the creativity and innovative capacity of children and young people through cultural expression and wider access to culture; 
- widen quality access to culture and creative tools, particularly those involving new technologies, and develop opportunities for youth people to experience culture and express and develop their creativity within or outside school;

- make new technologies readily available to empower young people's creativity and capacity for innovation, and attract interest in culture, the arts and science;

- provide access to environments where young people can develop their creativity and interests and spend a meaningful leisure time;

- facilitate long-term synergies between policies and programmes in the fields of culture, education, health, social inclusion, media, employment and youth with the view to promoting young people's creativity and capacity for innovation;

- promote partnerships between culture and creative sectors and youth organisations and youth workers;

- facilitate and support development of young people's talent and entrepreneurial skills with a view to enhancing their employability and future job opportunities;

- promote young people's knowledge about culture and cultural heritage in the different EU Member States, including through the use of new technologies" (The Council of European Union, 2009).

Despite the adopted resolutions, the recommendations, strategies and education development guidelines of the European Union and Education Area of Latvia, there is a particularly important issue of children and young people involvement in a meaningful life, due to the rapid changes, e.g. the degradation of values, variety of negative effects, such as impunity, delinquency, conflict, prostitution, etc.

There are different current problems in todays' education settings: number of single-parent families has grown up, the number of people severely affected by the economic problems has increased, homelessness, unemployment, children without parental supervision, children and young people who are victims of emotional or physical violence, etc. Thus a special attention to the students' education, development and improvement gains importance. Therefore, the development of students' social skills, empathy, communication, cooperation, their emotional awareness and control, adequate response to different situations and different abilities and skills necessary for integration into society becomes significant as well as the formation of personality's position (Божович, 2008). This can have a significant impact on students' professional activity in future; because the era of challenges determines that a person from childhood should be allowed to 
acquire a current knowledge of the world, with a help of other people and himself/herself.

\section{The explanation of comprehension of personality}

In order to implement the high quality education, it is important to understand the nature of personality and characteristics of its development. Researcher V. Batna (2001) points out that an individual becomes a personality in the relationships with others. At the same time it should be noted that there is no single theory of personality. It is recognized that there is a problem in psychology defining personality because in order to do it each person`s individually should be taken into account (Svence, 1999). Since this is not possible, the scientists are trying to find correlations that make up the similarities and differences. By studying human personality development scientists also take into account the individual`s needs and interests, as well as a motivation and self-assessment. It is recognized that personal development is driven by the need for self-realization and is influenced by heredity on the one hand and the external culture on the other.

Social psychologist Omārova S. (1997) indicates that an individual is a biological and social being, bringing together heredity, genetic program and knowledge gained in community. Scientist believes that personality is a set of individual's social characteristics, which is formed within living in a particular society, acquiring and processing an original social experience. Psychologist G. Svence (1999) points out that the personality is individual's internal dynamic organization, which includes motivation, habits, and personal characteristics that determine personal uniqueness in the appropriate setting. It should be noted that scientists believe that personality concept includes stable and unique examples of each person`s inherent thinking, emotional responses and behaviour. They are conditions that help an individual to adapt to the social environment and the specific life situations. It may be noted that there are no two identical personalities, so each person is individuality, personality, which is formed in the society, gaining new experience in the interaction with society members, engaging in social relations and the activities of the individual's socialization process. The preparation of living in a particular community can be both conscious and unconscious. Significant theoretical findings highlighted in the publication are done by psychologists V. Renge (1999) and Svence (1999, 2009), educator Gudjons H. (2007), social educator V. Batṇa (2001) and social psychologist S. Omārova (1997). The researchers of positive psychology focus on studying personal wellbeing related to the individual's creative potential and full implementation of resources, searching for strengths and emphasizing positive emotions and everyone's personal development (Svence, 2009). Teaching culture and educational philosophy of the 21st 
century provides the number of important aspects, e.g. personal, national and state identity, comprehension, creative self-expression, talent cultivation, self-development and self-realization, acquiring life, professional and social skills and skills necessary for career planning and personal growth. The aims of educational philosophy and pedagogical culture is provision of children`s and young people`s civic and value education and patriotic awareness in the process of formation of individual needs and desires in their personality development and career advancement, spending meaningful leisure time, broadening supply of education and accessibility. Involvement in various activities, including the ever broader, more complex relationships at school and outside it and ensuring self-realization needs can promote students comprehensive development.

\section{The importance of education in the personality development process}

UNESCO report indicates that the formal education system often is blamed for the limited self-fulfilment of personality, emphasizing the same cultural and intellectual model, without taking sufficient account of the diversity of individual talent. At the same time respecting the diversity and individuality is one of the main principles of the educational process. The imagination, ability to communicate, management talent are often not fully assessed in the formal education process.

Students' interests are different and the possible endangerment might occur, if the school is not suited to their interests, talents and abilities (Delors, 2001). That may be supplemented by teacher`s M. Skatkina (1985) findings, considering that it is not possible only within the framework of the particular subject to ensure the comprehensive development of students. Thus the importance of various extracurricular activities in the personality development process is highlighted.

Thinking about an all-round personality development, person`s involvement in different types of activities as well as teacher`s guidance gain importance. It must be admitted that without action the development is not possible. The main factors that affect student's positive attitude towards performance are the joy of success, the importance of public awareness, creativity and rich spiritual atmosphere (Skatkins, 1985). In order to implement such an approach, the importance of the teacher's applied forms of work and the nature of the relationship that is formed in the pedagogical process become significant. The cultivation of student`s and teacher`s mutual human relations is a leading motive of humanitarian pedagogy. In the organization of life of the new generation the maintenance of healthy lifestyle, intellectual and spiritual development and social activity acquire importance. 
Referring to the studies of K. Hurelman and D. Ulih three perspective orientations which are based on teacher activities can be viewed:

- "subject-oriented perspective. The emphasis is put on human growth and active role in the process of confrontation with the environment, to become a dynamic member of society;

- institutions-oriented perspective. The purpose and functions of public institutions are being evaluated, as well as performance, value and transferring culture techniques;

- culture-oriented perspective. It is evaluated as culture is passed on, as it is passed to the next generation to understand and be able to use it in own view of reality and self-understanding” (Hurrelmann, Uhlich, 1991, 8).

This framework exposes the analysis of the society on the one hand, but on the other hand psyche, point of contact in personality and personality development. To build a successful teaching culture, each teacher's professional development and its evaluation gain importance.

\section{The characteristics of teacher`s performance}

Rapid changes raise more new and responsible tasks for teachers. The teacher is the one who contributes to the future development of society, helps to raise awareness of current challenges without losing sight of the importance of social cohesion. UNESCO report highlights a number of important current issues for the implementation in quality education: to improve the teachers' personnel selection and preparation and improve the social status of teachers. It must be admitted that teacher must have the required knowledge and skills, personal qualities, professional development opportunities and motivation (Delors, 2001). Student`s and teacher`s relationship is one of the most important aspects of the implementation of the educational process. Teacher-student interaction is one of the most important elements of educational philosophy, searching for an answer to the question as to promote productive, purposeful, reciprocal and respectful cooperation (Schofield, 2012).Teachers communicating with learners tend to develop their personality, emphasizing self-confidence, encouraging reasoning, independence and responsibility. The teacher should be able to argue and rejoice together with students. In addition, to increase student s ability to express his/her view independently and autonomy would become a personality trait, it is also necessary to make it possible for students to feel like leaders.

Teacher's operational efficiency is characterized by a wide range of teaching skills, empathy, patience and humility. Teacher`s abilities and emotions are in close correlations with students' abilities, opportunities and emotions, while the harmony of them can generate real spiritual communion 
in the implementation of pedagogical process. The teacher's ability to engage students in their own personal development is an essential element in the context of humanitarian pedagogy.

Educator V. Šibajev (2002) points out that the formation of future society depends on the teacher's personality, professionalism, knowledge, understanding of values, the ability to change, focusing on growth. He emphasizes that the teacher's success is not only the knowledge and ability to conduct innovative activities, but also he/she must have the courage to change the context of education and continuous improvement.

The main motivational aspects for the teacher proficiency are: the teacher needs; teacher's interest in self-improvement; teacher's imagination, intuition, which is based on the higher expectations, unusual vision; teacher's feelings which makes person spiritually richer; teacher's internal contradictions, conflicts, contributing to a faster search of answers and encouragement. It may be noted that three basic ideas contributing teacher`s proficiency are:

- "professional teacher is dynamic with active attitude towards themselves and the world around them;

- subject's activity is realized in a creative attitude to the world around him/her;

- creative, diverse activities are the basis for compliance with internal motivation, personal growth" (Šibajevs, 2002, 12).

The quality of education is one of the most topical problems. An important aspect in this context is a teacher`s professional development. UNNESCO report states that teacher`s quality and motivation for improvement should be a priority in all countries (Delors, 2001). Based on Šibajev V. (2002), teacher`s professional activity functions are strengthened by vitality, socialization, freedom of conscience, evaluative, organizational, innovative research, communicative and humanitarian approach. These features through interrelation affect teacher`s and all teachers' collective professionalism. Thus, the teacher can fulfil its most important task, and promote the humane personality growth.

Referring to the teacher`s V. Šibajevs belief, teacher's personality characteristics and professional competence are the most important aspects in order to purposefully implement the education guidelines (Šibajevs, 2002). There is a chance for teacher to make self-assessment of his/her pedagogical competences periodically through evaluating personal teaching activities and making own portfolio.

To do this it is necessary to identify the key criteria that have been developed in accordance with the characteristics of the development of education in Europe and Latvia in the contemporary context, through adapting teacher`s operational aspects worked out by Hurelmana K. and D. 
Uliha: subject, institutions, culture, as well as the assessment of planning skills of the learning process and in the upbringing process, implementation of pedagogical communication, the possibility of creating a democratic dialogue, laying the foundation for future reconciliation and peace, be tolerant towards other cultures, as well as the evaluation of professional development in the appreciable period. Relevant activities are carried out and self-assessment levels (low, medium, high) are described according to the criteria.

In accordance with the evaluation criteria, it is possible to identify the pedagogical fields, which require development. This helps the teacher choose and plan potential opportunities of further education. Carried out selfassessment allows to set the perspective of the opportunities of the pedagogical professional competence development ad to put forward specific objectives for its implementation.

\section{Conclusion}

1. The development of education system of Latvia is being implemented and carried out in accordance with international and country specific frameworks, guidelines, recommendations and documents, recognizing the characteristics of existing cultural space of Latvia. At the same time it can be concluded that the implementation of education in Latvia requires dynamic changes in the field of problem solving, gaining and searching for answers to key issues raised in educational philosophy.

2. Teacher needs to be in the process of self-development, towards the improvement of the ability to operate and cooperate and the ability to live alongside. Self-assessment is one of the measures for the assessment of pedagogical competence. The improvement of professional qualifications forms of teachers is becoming increasingly important and the field of education is acquiring more complex nature. In this context, the proficiency of teacher as well as his/her competences gain special attention in order to prepare students for a rapidly changing era.

3. Teacher`s professional development and work is in the close conjunction with the quality of education. Such quality of education, which will greatly affect a person's life, activities and levels of consciousness: emotional experience level related with the event; the level of harmonization of human and environment; the level of corroboration of person's social status; human skills, creativity, ability and talent.

4. The strategic guidelines of the European Union emphasize that the development of general skills and the importance of cultural and creative understanding are important issues in the field of education for the next decade. As a new feature of the 21st century the knowledge in the particular field is aging already during the learning process, thus fundamental 
knowledge acquisition becomes more important. This approach is more sustained, leads to the development of information extraction skills, selfeducation and lifelong learning issues. This raises an important question: Are professionals involved in education, willing to recognize that we can help and ensure our students to make a successful choice to be able to realize their personal potential in their lives?

5. It should be noted that the theoretical analysis within the publication strengthens the need for additional studies in the field of educational philosophy in the cultural space of Latvia.

\section{References:}

1. Alijevs, R. (2005). Izglìtības filosofija 21. gadsimts. Rīga: Retorika, 287 lpp.

2. Batņa, V. (2001). Rosinot bērna iekšějo pasauli. Rīga: RaKa, 280 lpp.

3. Delors, Ž. (2001). Mācīšanās ir zelts. Rīga: Poligrāfijas grupa „Remarks - R”, 120 lpp.

4. Gadamers, H. G. (1999). Patiesība un metode: filosofiskas hermeneitikas pamatiezīmes. Rīga: Jumava, 508 lpp.

5. Gudjons, H. (2007). Pedagogijas pamatatziņas. Rīga: Zvaigzne ABC, 394 lpp.

6. Helds, J. (2004). Kooperatīvā mācīšanās un skolēns kā subjekts. Kooperatīvā mācīšanās. Rīga: RaKa, 215 lpp.

7. Huntington, S. (1996). The clash of civilizations and the remaking of world order. New York: TOUCHSTONE Rockefeller Center, 368 p.

8. Hurrelmann, K., Ulich, D. (1991). Neues Handbuch der Sozialisationsforschung. Beltz: Bad Langensalza, 745 p.

9. Omārova, S. (1997). Cilvēks dzīvo grupā. Rīga: Kamene, 187 p.

10. Reñge, V. (1999). Psihologija. Personības psihologiskās teorijas. Rīga: Zvaigzne ABC, 174 lpp.

11. Siegel, H. (2009). Introduction: Philosophy of Education and Philosophy. In H. Siegel (Ed.) The Oxford Handbook of Philosophy of Education (pp. 3-8). Oxford: Oxford University Press, 548 p.

12. Skatkins, M. (1985). Skola un bērnu vispusīga attīstība. Rīga: Zvaigzne, 142 lpp.

13. Svence, G. (1999). Attīstības psihologija. Rīga: Zvaigzne ABC, 158 lpp.

14. Svence, G. (2009). Poziț̄ìa psihologija. Rīga: Zvaigzne ABC, 215 lpp.

15. Schofield, H. (2012). The philosophy of education an introduction. Volume 154. Oxon: Routledge, 287 p. 
16. Šibajevs, V. (2002). Neformālā izglìtība interešu centros. Rīga: RaKa, 351 lpp.

17. Špona, A. (2001). Audzināšanas teorija un prakse. Rīga: RaKa, 162 lpp.

18. The Council of European Union. (2009). Council resolution of 27 November 2009 on a renewed framework for European cooperation in the youth field (2010-2018). Available: http://eurlex.europa.eu/legalcontent/EN/TXT/?uri=CELEX\%3A32009G1219(01)

19. Божович, Л. (2008). Личность и ее формирование в детском возрасте. Санкт-Петербург: Издательский дом «Питер», 400 стр.

20. Огурцов, А.., Платонов, В. (2004). Образы образования. Западная философия образования. ХХ век. Санкт-Петербург: Русский христианский гуманитарный институт, 520 стр. 